\title{
A REVIEW OF THE IMPORTANCE, DETECTION AND CONTROLLING OF HEAVY METAL IN MILK AND DAIRY PRODUCTS
}

\author{
Razzagh Mahmoudi $^{1^{*}}$, Masoud Kazeminia ${ }^{2}$, Ata Kaboudari ${ }^{3}$, SeyedehFaezehRahimiPir- \\ Mahalleh $^{3}$, Babak Pakbin ${ }^{4}$ \\ ${ }^{1}$ Health Products Safety Research Center, Qazvin University of Medical Sciences, Qazvin, Iran. \\ ${ }^{2}$ M.Sc. in Food Hygiene and Safety, Qazvin University of Medical Sciences, Qazvin, Iran. \\ ${ }^{3}$ D.V.M Student, Faculty of Veterinary Medicine, University of Tabriz, Tabriz, Iran. \\ ${ }^{4}$ Department of Food Hygiene and Quality Control, Faculty of Veterinary Medicine, University of Tehran, Tehran, \\ Iran. \\ *Corresponding Author: r.mahmodi@yahoo.com \\ Received: 9 Jan 2016 \\ Revised: 16 Feb 2017 \\ Accepted: 27 Feb 2017
}

\begin{abstract}
Milk and dairy products can be contaminated in different ways. One of the most important and most challenging contaminations is due to heavy metals. In present research key words, including Milk, Dairy products, Heavy metal, Iran in the database pub med, Science Direct, Elsevier, SID, MagIran, Civilica, the World Health Organization and Agriculture Organization of the United Nations were searched. All articles indexed in domestic and international journals related to the topic were collected over the past several years. Heavy metal contamination in milk and dairy products play an important role in public health, as it can be the reason to the prevalence of diverse illnesses and lesions. There are various ways to measure the amount of contamination in milk and dairy products. One of the best and most efficient methods is atomic absorption. Moreover, collecting samples, storing and preparing them with different materials and solutions are also an important method. Heavy metals can enter the food chain in many ways. Sewage, factory waste, garbage, dust and etc are the common ways for heavy metals to enter the food. Cow's body acts like a biological filter about heavy metals, especially Cadmium and the absorbed Lead and Cadmium move to its bones and start to accumulate. Due to extensive consumption of milk and dairy products, it is critical to lessen contamination. Water and foods with both animal and plant resources must be monitored and examined before use. Materials used for food packaging must be harmless for human health so the present elements used in the containers must be reconsidered.
\end{abstract}

Key words: Milk, Dairy products, Heavy metal, Iran

\section{INTRODUCTION}

Milk and dairy products can be contaminated by different sources such as heavy metals, mycotoxins and veterinary drugs residues. One of the most important and most challenging contaminations is due to heavy metals such as Lead, Cadmium, Cobalt, Nickel, Arsenic and Tin (Rokni., 2007; Mahmoudi et al., 2013; Fallah et al., 2015; Mahmoudi et al., 2015). Heavy metals have higher density comparing to other metal elements. In average their density is higher than $5 \mathrm{gr} / \mathrm{cm}^{3}$ (Eskandari \& Pakfetrat., 2014). 
Nowadays heavy metals contaminating milk and dairy products especially Lead and Cadmium play an important role in public health as it can be the reason to the prevalence of divers illnesses and lesions (Rokni., 2007; Fallah et al., 2015). After entering the body, Lead starts to accumulate in different tissues such as liver and kidneys and disrupts their physiological performance. Lead is also known as one of the factors in respiratory inflammation, failure and tumor (Correia et al., 2000; Mahmoudi \& Zare., 2013; Mahmoudi \& Norian., 2014).

The most common symptoms of lead poisoning are anemia and loss of color factor in the blood, caused by iron deficiency (Jeng et al., 1994). Cadmium is known as one of the important factors in bladder and prostate cancer (Ballantyne et al., 2009).

Cadmium's accumulation in the body increases the risk of developing cancer, high blood pressure, iron deficiency, liver diseases and neurological damages (Jeng et al., 1994).

Heavy metals aren't metabolized in the body and are liable to different bacterial, viral and fungal diseases in the host's body (Rokni.,
2007; Eskandari \& Pakfetrat., 2014). It has also been approved that the impact of high concentrations of heavy metals in a short period of time has similar effects as of low concentrations in a long period of time environmental organization has introduced Lead and Cadmium as the most harmful heavy metals (Hamidpour et al., 2011; Mahmoudi et al., 2015).

Lead and Cadmium are not the only sources of chemical contamination caused by heavy metals. Metals and elements such as Iron, Zinc, Manganese and Magnesium components are micronutrients and milk products are major source of these elements. If the amount of these metals and elements exceeds of limit the product is contaminated (Li et al., 2005).

Metals such as lead and cadmium are under no circumstances necessary for the body, but metals such as copper, iron and zinc are necessary for normal functioning of body (Ayar et al., 2009; Qin et al., 2009; Khan et al., 2013; Li et al., 2005; FARID 2004; Goyer., 1995).

Permitted levels of lead and cadmium in raw milk by the Codex Alimentarius 2000 (Committee on Food Additives, Geneva 
Study) respectively are $1 \mathrm{ppm}$ and 0.010 ppm (Bonyadian et al., 2006).

\section{METHODS}

In this paper key words, including Milk, Dairy products, Heavy metal, Iran in the database pub med, Science Direct, Elsevier, SID, MagIran, Civilica, the World Health Organization and Agriculture Organization of the United Nations were searched. All articles indexed in domestic and international journals related to the topic were collected during the two decades.

\section{RESULTS}

\section{Methods of measurement}

Various methods for measuring heavy metals in milk and dairy products have been defined. One of the best and most practical methods is atomic absorption spectrometry. The method of sample collection storage and processing them using a variety of materials and solutions is also important (Belete et al., 2014). Another method is graphite oven atomic absorption measurements (Licata et al., 2004).
For the measurement of very small amounts of cadmium on the scale of ppt, micro scatterer distribution of solvent followed by solidification by reducing the temperature can be demonstrated (Jahromi et al., 2007).

Cover analysis of potentiometric method is another method of measuring heavy metals in milk and dairy products.The atomic absorption method is cheaper and more accurate comparing to this method (Jeng et al., 1994).

\section{Heavy metals in milk}

There have been few researches done on contamination of raw and pasteurized milk. Obtained reports indicate the presence of contamination in Iran (Eskandari \& Pakfetrat., 2014).

The study conducted by Rahimi and Derakhshesh (2010) showed that the contamination of cow's raw milk by cadmium has various levels in different cities. Industrial cadmium pollution in densely populated areas such as Tehran and Isfahan, Ahvaz, and Ghom is more compared to Rasht, Shiraz and Yazd (Rahimi \& Derakhshesh., 2010).

The survey of some heavy metal contamination in raw milk samples, results 
showed that the levels of lead and chromium has exceeded the permissible limit in some areas of the province (Javadi et al., 2005).

The results of Tajkarimi et al (2008) on raw cow milk lead contamination by using atomic absorption spectrometry showed that the average amount of lead in all samples was $7.900 \mathrm{ng} / \mathrm{mL}$, which was calculated by.

Less than $10 \%$ of the samples were greater than $22 \mathrm{ng} / \mathrm{ml}$ and $60 \%$ of the samples were between 1.100 to $5.700 \mathrm{ng} / \mathrm{ml}$. The lead contamination of raw milk in Tehran, Isfahan and West Azarbayjan was more than other areas. Therefore these areas require more attention (Tajkarimi et al., 2008).

In a study Conducted by Bonyadian et al (2006) on lead and cadmium contamination in raw and pasteurized milk in Shahrekord, the results showed that the lead and cadmium levels in all samples were below the limit. also the level of contamination in raw milk is much more significant than in pasteurized milk (Bonyadian et al., 2006). In other study in the industrial city of Arak, the contamination of pasteurized milk to iron, lead and zinc was determined by microwave digestion, resulting in the fact that the amount of iron was over the permissible limit (Alebi., 1998).

In study of Parveez Mand Zamaian (2001) was conducted on lead and cadmium levels in pasteurized milk in 2 large milk processing factories in Tehran. Lead and cadmium were found in all samples, but the amount wasn't determined (Parveez Mand Zamaian., 2001).

In the study of Chinikar et al (1997) the contamination of four types of milk (Raw milk, Pasteurization milk, Powdered milk and Human breast milk) caused by nickel, lead, copper and cadmium was calculated by atomic absorption spectrometry. The results showed that $2.840 \%$ of the samples were contaminated to lead and $4.610 \%$ of the samples were contaminated to cadmium. The average amounts of lead, nickel, cadmium and copper were obtained respectively 1.200 ppm, 42 ppm, 14 ppm, 34 ppm, (Chinikaar., 1997).

The results of various studies on heavy metal contamination in milk and dairy products in Iran show that in table 1, 2. 
Table 1. Heavy metal Contamination in milk samples and comparing them with the permissible limit

\begin{tabular}{|c|c|c|c|c|c|c|c|c|}
\hline \multirow{2}{*}{ Sample } & \multirow{2}{*}{$\begin{array}{c}\text { number } \\
\text { of } \\
\text { sample } \\
\text { s } \\
\end{array}$} & \multicolumn{2}{|c|}{ Metal } & \multirow{2}{*}{\multicolumn{2}{|c|}{ Standard }} & \multirow{2}{*}{$\begin{array}{c}\text { Non- } \\
\text { standard }\end{array}$} & \multirow{2}{*}{ Region } & \multirow{2}{*}{ Reference } \\
\hline & & \multicolumn{2}{|c|}{ Measured values (ppb) } & & & & & \\
\hline & \multirow{2}{*}{12} & \multicolumn{2}{|c|}{$\mathrm{Cd}$} & \multirow{2}{*}{\multicolumn{2}{|c|}{ * }} & & \multirow{2}{*}{ Isfahan } & Rahimi \& \\
\hline & & \multicolumn{2}{|c|}{ 0/007 } & & & & & $\begin{array}{l}\text { Derakhshesh., } \\
2010\end{array}$ \\
\hline & \multirow{2}{*}{8} & \multicolumn{2}{|c|}{$\mathrm{Cd}$} & \multirow{2}{*}{\multicolumn{2}{|c|}{ * }} & & \multirow{2}{*}{ Tabriz } & Rahimi \& \\
\hline & & \multicolumn{2}{|c|}{$0 / 005$} & & & & & 2010 \\
\hline & \multirow{2}{*}{6} & \multicolumn{2}{|c|}{$\mathrm{Cd}$} & \multicolumn{3}{|c|}{$*$} & \multirow{2}{*}{ Sanandaj } & Rahimi \& \\
\hline & & \multicolumn{2}{|c|}{$0 / 002$} & & & & & 2010 \\
\hline & \multirow{2}{*}{10} & \multicolumn{2}{|c|}{$\mathrm{Cd}$} & \multirow{2}{*}{\multicolumn{2}{|c|}{$*$}} & & \multirow{2}{*}{ Tehran } & Rahimi \& \\
\hline & & \multicolumn{2}{|c|}{ 0/009 } & & & & & 2010 \\
\hline & & & & & & & & Rahimi \& \\
\hline & 5 & & & & & & Yazd & $\begin{array}{l}\text { Derakhshesh., } \\
2010\end{array}$ \\
\hline & & & & & & & & Rahimi \& \\
\hline & 9 & & & & & & Sniraz & $\begin{array}{l}\text { Deraknsnesn., } \\
2010\end{array}$ \\
\hline & 11 & & & & & & Chom & Rahimi \& \\
\hline & & & & & & & UñIII & 2010 \\
\hline & 10 & & & & & & A & Rahimi \& \\
\hline $\begin{array}{l}\text { Raw cow } \\
\text { milk }\end{array}$ & 10 & & & & & & Anvaz & $\begin{array}{l}\text { Deraknsnesn., } \\
2010\end{array}$ \\
\hline & & & & & & & & Rahimi \& \\
\hline & 5 & & & & & & Yasouj & $\begin{array}{c}\text { Derakhshesh., } \\
2010\end{array}$ \\
\hline & 10 & & & & & & & Rahimi \& \\
\hline & 10 & & & & & & IVtasminau & 2010 \\
\hline & & & & & & & & Rahimi \& \\
\hline & 1 & & & & & & Kasmit & 2010 \\
\hline & & & & & & & & Rahimi \& \\
\hline & 8 & & & & & & Kerman & $\begin{array}{l}\text { Derakhshesh., } \\
2010\end{array}$ \\
\hline & & & & & & * & & Radmehr et al., \\
\hline & 100 & & & & & $*$ & Tehran & 2010 \\
\hline & 100 & $\mathrm{Cd}$ & $\mathrm{Pb}$ & $\mathrm{Cd}$ & $\mathrm{Pb}$ & $\mathrm{Cd} \quad \mathrm{Pb}$ & Zahol & Moallembandan \\
\hline & & $4 / 557$ & $9 / 175$ & $*$ & $*$ & & & i et al., 2014 \\
\hline & & $\mathrm{Cd}$ & $\mathrm{Pb}$ & $\mathrm{Cd}$ & $\mathrm{Pb}$ & $\mathrm{Cd} \quad \mathrm{Pb}$ & & Vahidi nia et \\
\hline & 48 & $3 / 210$ & $4 / 860$ & $*$ & $*$ & & Hamedan & al., 2013 \\
\hline & & $\mathrm{Cd}$ & $\mathrm{Pb}$ & $\mathrm{Cd}$ & $\mathrm{Pb}$ & $\mathrm{Cd} \quad \mathrm{Pb}$ & & Yasaei \\
\hline & $2 J$ & $0 / 582$ & $7 / 200$ & * & $*$ & & Yazd & $\begin{array}{l}\text { Menrgray., } \\
2009\end{array}$ \\
\hline
\end{tabular}




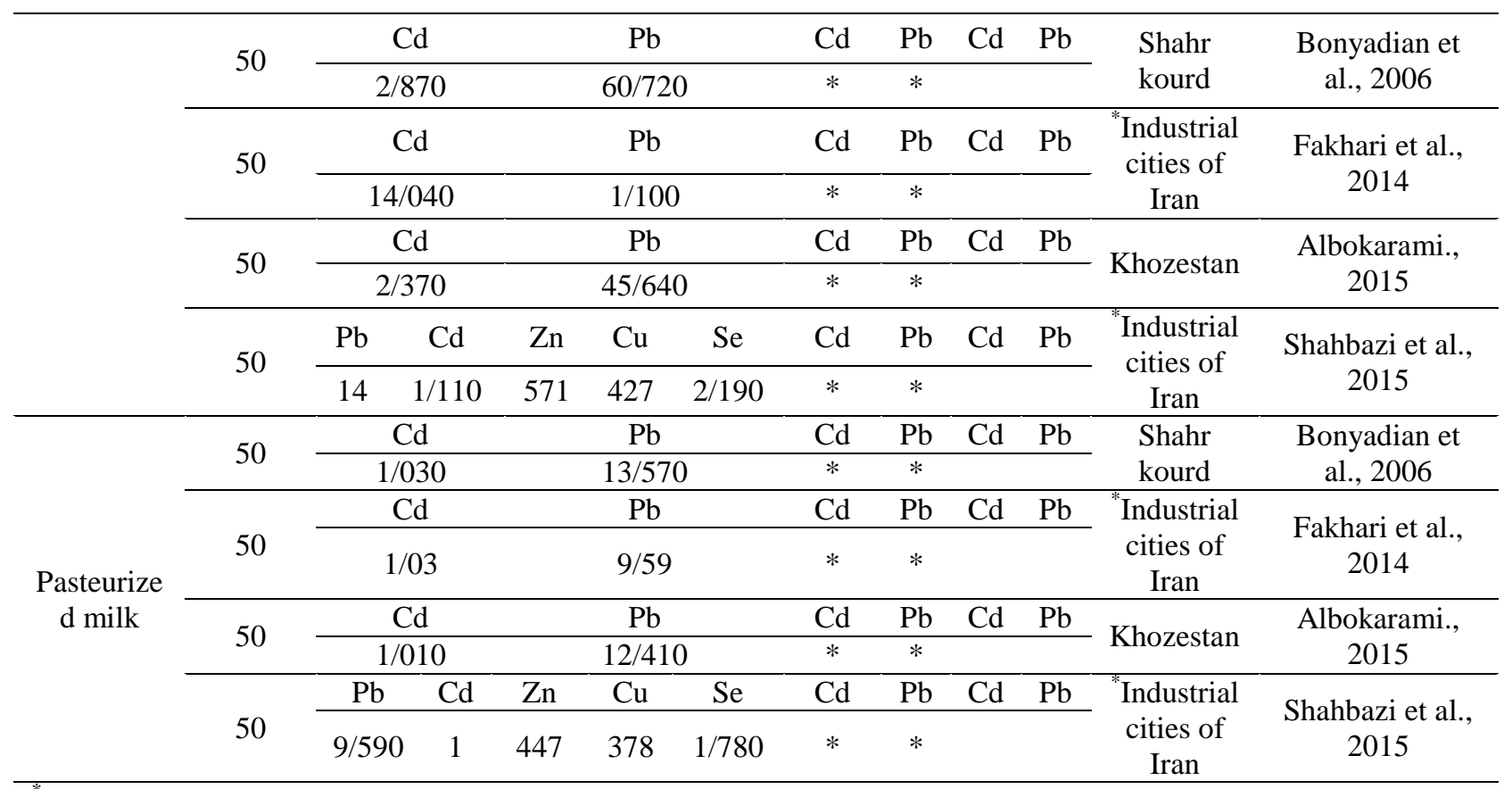

*Industrial cities of Iran include Isfahan, Ahvaz, Tehran, Tabriz and Mashhad.

The measuring of the samples showed that the heavy metal level in more samples were lower than the global standard, so all of the collected fresh milk was clean, pure and safe and also The pasteurization process may reduce the concentration of lead and cadmium in milk.

\section{Heavy metals in dairy products}

There have been few studies on heavy metals in dairy products (yogurt, cheese, butter, cream, whey, doogh, curd and milk powders) in Iran. In study of Mohammadi sani et al (2009) calculated the amount of copper, iron, zinc, arsenic, lead, cadmium and calcium in curd using the atomic absorption spectrometry method in
Khorasan province. In this study copper, iron and arsenic levels exceeded the standards set by national organizations (Mohammadi sani et al., 2009).

In another study, the contamination of Ultra Filtrate cheese and yoghurt with cadmium and lead in the province of Isfahan was determined using atomic absorption spectrometry and oven according to AOAC guidelines. The results showed that the concentration of lead and cadmium samples tested are $200 \mathrm{ppb}$ which is in the range of international standards (Jaberi et al., 2013).

In other study on lead and cadmium contamination in milk and its products (skim milk and cream) in Isfahan (Iran), showed 
that the amount of lead is in the permissible range but cadmium has exceeded the limit set by the Codex Alimentarius (Shakerian \& Karim., 2004).

In study of Emamian (2005) in Shahrekord city was conducted to determine the amount of lead and cadmium using the potentiometric method, using 12 samples of raw milk, 12 samples of skim milk, 12 samples of cream and 12 samples of pasteurized milk. Results showed $58 \%$ of the raw milk samples, cadmium had exceeded the limit (Emamian., 2005).

Another study on the amount of copper and lead in baby food and formula in Iran, showed that the amount of copper had exceeded the limit (Poursartip., 1999).

In another study on two types of powdered milk using the spectrometry method, the amount of lead in both cases was over the permissible amount (Navab irani M., 2000).

Table 2. Heavy metal Contamination in dairy products samples and comparing them with the permissible limit

\begin{tabular}{|c|c|c|c|c|c|c|c|c|c|c|c|c|}
\hline \multirow{4}{*}{$\begin{array}{c}\text { Sample } \\
\text { Milk } \\
\text { powders }\end{array}$} & \multirow{4}{*}{$\begin{array}{c}\begin{array}{c}\text { Number } \\
\text { of } \\
\text { samples }\end{array} \\
25\end{array}$} & \multirow{2}{*}{\multicolumn{5}{|c|}{$\begin{array}{c}\text { Metal } \\
\text { Measured values (ppb) }\end{array}$}} & \multirow{2}{*}{\multicolumn{2}{|c|}{ Standard }} & \multirow{2}{*}{\multicolumn{2}{|c|}{$\begin{array}{c}\text { Non- } \\
\text { standard }\end{array}$}} & \multirow{4}{*}{$\begin{array}{l}\text { Region } \\
\text { Tehtran }\end{array}$} & \multirow{4}{*}{$\begin{array}{c}\text { Reference } \\
\text { Mollaei } \\
\text { Parvary et } \\
\text { al., } 2015\end{array}$} \\
\hline & & & & & & & & & & & & \\
\hline & & \multicolumn{2}{|l|}{$\mathrm{Cd}$} & \multicolumn{2}{|r|}{$\mathrm{Pb}$} & & $\mathrm{Cd}$ & $\mathrm{Pb}$ & $\mathrm{Cd}$ & $\mathrm{Pb}$ & & \\
\hline & & \multicolumn{2}{|c|}{$14 / 110$} & \multicolumn{3}{|c|}{$57 / 360$} & & $*$ & $*$ & & & \\
\hline \multirow[b]{2}{*}{$\begin{array}{c}\text { Milk } \\
\text { powders }\end{array}$} & \multirow[b]{2}{*}{25} & \multicolumn{2}{|l|}{$\mathrm{Cd}$} & \multicolumn{3}{|c|}{$\mathrm{Pb}$} & $\mathrm{Cd}$ & $\mathrm{Pb}$ & $\mathrm{Cd}$ & $\mathrm{Pb}$ & \multirow{2}{*}{$\begin{array}{l}\text { * Some of } \\
\text { the cities } \\
\text { in Iran }\end{array}$} & \multirow{2}{*}{$\begin{array}{c}\text { Malakootian } \\
\& \\
\text { Golpayegani } \\
2013\end{array}$} \\
\hline & & \multicolumn{2}{|c|}{$7 / 240$} & \multicolumn{3}{|c|}{$37 / 600$} & $*$ & $*$ & & & & \\
\hline \multirow{2}{*}{ Yogurt } & \multirow{2}{*}{12} & \multirow{2}{*}{\multicolumn{2}{|c|}{$\frac{\mathrm{Cd}}{18 / 070}$}} & \multicolumn{3}{|c|}{$\mathrm{Pb}$} & $\mathrm{Cd}$ & $\mathrm{Pb}$ & $\mathrm{Cd}$ & $\mathrm{Pb}$ & \multirow{2}{*}{ Isfahan } & \multirow{2}{*}{$\begin{array}{c}\text { Jaberi et al., } \\
2013\end{array}$} \\
\hline & & & & & $58 / 305$ & & $*$ & $*$ & & & & \\
\hline \multirow{2}{*}{ Cheese } & \multirow{2}{*}{12} & \multirow{2}{*}{\multicolumn{2}{|c|}{$\frac{\mathrm{Cd}}{45 / 730}$}} & & $\mathrm{~Pb}$ & & $\mathrm{Cd}$ & $\mathrm{Pb}$ & $\mathrm{Cd}$ & $\mathrm{Pb}$ & \multirow{2}{*}{ Isfahan } & \multirow{2}{*}{$\begin{array}{c}\text { Jaberi et al., } \\
2013 \\
\end{array}$} \\
\hline & & & & & $123 / 660$ & & & & $*$ & $*$ & & \\
\hline \multirow[b]{2}{*}{ Cheese } & \multirow[b]{2}{*}{50} & $\mathrm{~Pb}$ & $\mathrm{Cd}$ & $\mathrm{Zn}$ & $\mathrm{Cu}$ & $\mathrm{Se}$ & $\mathrm{Cd}$ & $\mathrm{Pb}$ & $\mathrm{Cd}$ & $\mathrm{Pb}$ & \multirow{2}{*}{$\begin{array}{l}\text { Industrial } \\
\text { cities of } \\
\text { Iran }\end{array}$} & \\
\hline & & $14 / 500$ & $1 / 250$ & 586 & 428 & $1 / 680$ & $*$ & $*$ & & & & $\begin{array}{l}\text { Shanbaz1 et } \\
\text { al., } 2015\end{array}$ \\
\hline & & $\mathrm{Pb}$ & $\mathrm{Cd}$ & $\mathrm{Zn}$ & $\mathrm{Cu}$ & $\mathrm{Se}$ & $\mathrm{Cd}$ & $\mathrm{Pb}$ & $\mathrm{Cd}$ & $\mathrm{Pb}$ & Industrial & \\
\hline Yogurt & 50 & $7 / 540$ & 0/990 & 431 & 399 & $1 / 230$ & $*$ & $*$ & & & $\begin{array}{l}\text { cities of } \\
\text { Iran }\end{array}$ & al., 2015 \\
\hline & & $\mathrm{Pb}$ & $\mathrm{Cd}$ & $\mathrm{Zn}$ & $\mathrm{Cu}$ & $\mathrm{Se}$ & $\mathrm{Cd}$ & $\mathrm{Pb}$ & $\mathrm{Cd}$ & $\mathrm{Pb}$ & Industrial & \\
\hline Doogh & 50 & $7 / 200$ & $0 / 840$ & 369 & 320 & 0/99 & $*$ & $*$ & & & $\begin{array}{l}\text { cities of } \\
\text { Iran }\end{array}$ & al., 2015 \\
\hline & & As & $\mathrm{Cu}$ & $\mathrm{Pb}$ & $\mathrm{Cd}$ & $\mathrm{Zn}$ & $\mathrm{Cd}$ & $\mathrm{Pb}$ & $\mathrm{Cd}$ & $\mathrm{Pb}$ & & Mohammadi \\
\hline Curd & 50 & $3 / 541$ & $3 / 229$ & $0 / 216$ & $0 / 100$ & $8 / 191$ & $*$ & $*$ & & & Khorasan & $\begin{array}{c}\text { sani et al., } \\
2009\end{array}$ \\
\hline Whey & 12 & $\mathrm{~Pb}$ & $\mathrm{Cd}$ & As & $\mathrm{Hg}$ & $\mathrm{Al}$ & $\mathrm{Cd}$ & $\mathrm{Pb}$ & $\mathrm{Cd}$ & $\mathrm{Pb}$ & Khorasan & Ebdali \\
\hline
\end{tabular}




\begin{tabular}{rlllllll}
\hline 18 & 1 & $<20$ & 1 & 2679 & $*$ & $*$ & taklou., \\
2013
\end{tabular}

** Industrial cities of Iran include Isfahan, Ahvaz, Tehran, Tabriz and Mashhad.

\section{Sources of contaminations}

Heavy metals enter the food chain by different ways. Sewage, waste from manufacturing activities, dust and heavy metals in food are the usual ways. Contaminated soil also has high impact (Eskandari \& Pakfetrat., 2014; Fallah et al., 2015). Studies have showed that cadmium concentrations in the milk of cows which have been raised in industrial areas and next to the highways or animals which are fed with food contaminated with heavy metals is much higher than of animals that are bred in cleaner areas (Pavlović et al., 2004; Patra et al., 2008).

Phosphate fertilizers contain heavy metals such as cadmium and nickel. Therefore extreme use of fertilizers not only accumulates in the soil, it also reduces soil microbial activity and thus they're absorbed by the plants, and enter the chain of animal and human (Garcia et al., 1999).

Cadmium is dispersed with a high extent in the environment, and it is mostly available in industrial compounds and phosphate fertilizers (Jeng et al., 1994).
In the study of Radmehr et al (2010) the amount of lead in milk of dairies around Tehran had lead levels which were higher than the standard limit but in their drinking water, except for 2 samples, others had permissible amount of lead. As a result water cannot be an effective source of lead pollution (Radmehr et al., 2010).

\section{Reducing the contaminations}

Cow's body acts like a biological filter about heavy metals (especially Cadmium). The absorbed Lead and Cadmium move to its bones and start to accumulate. Under special circumstances, such as excessive levels of metals in the animal's body or lack of dietary calcium, it can be excreted into breast milk (Eskandari \& Pakfetrat., 2014).

Lead and tin can also enter the food through packaging, for instance Lighvan canned cheese in Iran (Essentail Korfali \& Hamdan., 2013).

According to the results of a study on metal pollution in cheese and white cheese, lead 
contamination had occurred through gallon containers (Abdalla et al., 2013).

Nurdin et al (2013) studied on the effect of some medicinal plants used in the diet which can reduce the amount of lead excreted in the animal's milk. Their results showed that the cumin, white turmeric and mango turmeric can reduce the amount of lead in milk and its products by 98.36 , 99.33 and 99.37 percent, respectively (Nurdin et al., 2013).

In another study, the amount of metal elements in milk and its products were examined. The amount of iron, copper, manganese, zinc, lead, cadmium and chromium had reduced by $0.40-15 \%$ in cow milk's yoghurt and $0.50-15 \%$ in buffalo milk's yoghurt. The amount of nickel, cobalt and tin had reduced by $50-100 \%$ in cow milk's yoghurt and $25-50 \%$ in buffalo milk yoghurt. As a result, the amount of these metals sharply decreases in the process of yoghurt production, which is due to high acidity and bacterial activity (Enb et al., 2009).

There have been extensive studies on the removal of heavy metal contamination from various sources, especially water resources. This method can be generalized to decontamination of various dairy products, especially lead and cadmium. In the past few years, mineral absorbents such as smectite and Palygorsctite have been used to absorb heavy metals (Farrah \& Pickering., 1997).In another study Sepiolite minerals and zeolites were introduced as adsorbents and corrective agents for heavy metals (Shirvani et al., 2006). In another study modified rice husk with different concentrations of sodium bicarbonate were used to absorb low concentrations of cadmium in aqueous environments (Shahmohammadi et al., 2008).

The studies proved that some lactobacillus species use heavy metals in their metabolism. Using these lactobacilli as probiotic agents can reduce the contamination by absorbing heavy metals from products such as yogurt (Penaud et al., 2006).

Heavy metals bond with some lactobacilli specific proteins (LAB), afterwards they are absorbed and eliminated biologically (Kinoshita et al., 2013). 


\section{CONCLUSIONS}

Heavy metal contamination in milk and dairy products play an important role in public health, as it can be the reason to the prevalence of diverse illnesses and lesions due to extensive consumption of thes products. Water and foods with both animal and plant resources must be monitored and examined before use. Materials used for food packaging must be harmless for human health so the present elements used in the containers must be reconsidered. Using absorbent and neutralizing agents is also an effective way to reduce the contaminations, such as using probiotic bacteria.

\section{REFERENCES}

Abdalla MI., Algunaid FH. (2013). Minerals composition $(\mathrm{Ca}, \mathrm{Na}, \mathrm{Pb}$ and $\mathrm{Sn})$ of Sudanese white soft cheese. Agricultural Advances 2(4): 129-134.

Albokarami H. (2015). Determination of $\mathrm{Pb}$ and $\mathrm{Cd}$ in raw and pasteurized milk produced Shadegan city. International Conference on Engineering and Applied Sciences,
Dubai, Institute of Directors thinker capital Vieira.

Alebi Z. (1998). Determination and measurement of Lead, Zinc and Iron in Arak's pasteurized milk using Microwave Digestion Method. Second seminar of dairy products. Mashhad Ferdowsi University, September1-2,Mashhad, Iran.

Ayar A., Sert D. \& Akın N. (2009). The trace metal levels in milk and dairy products consumed in middle Anatolia-Turkey. Environmental monitoring and assessment 152(1-4): $1-12$.

Ballantyne B., Marrs TC., Syversen T. (2009). Basic elements of toxicology. General, Applied and Systems Toxicology. Pp:275-294. 6 Volume Set, 3rd Edition.

Belete T., Hussen A. \& Rao VM. (2014). Determination of concentrations of selected heavy metals in cow's milk: Borena Zone, Ethiopia. Journal of Health Science 4(5): 105-112.

Bonyadian M., Moshtaghi H. \& Soltany Z.(2006). Study on the residual of lead and cadmium in raw and 
pasteurized milks in Shahrekord area. Iranian Veterinary Journal 2(2): 7481.

Chinikaar S., Amirkhani A., Kodaei P., Asmar M. \&Saghiri R. (1997). Survey on the heavy metalsin consumer milk using atomic absorption method. 4th Congress of Biochemistry, Babol University of MedicalSciences. 1997 October 1922, Babol, Iran.

Correia PRM., Oliveira ED. \& Oliveira PV.(2000). Simultaneous determination of $\mathrm{Cd}$ and $\mathrm{Pb}$ in foodstuffs by electrothermal atomic absorption spectrometry. Analytica chimica acta 405(1): 205-211.

Ebdali taklou I. (2013). The amount of contaminants present in sweet whey powder, whey products. Twenty-first National Congress of Food Science and Technology, Shiraz, Shiraz, University.

Emamian SA. (2005). Determination of lead and Cadmium in milk and dairy products in Share Kordusing Potentiometric Stripping Analyzer. Thesis, Faculty of Veterinary
Medicine, Share Kord Islamic AzadUniversity 273.

Enb A., Abou Donia MA, Abd-Rabou NS., Abou-Arab AAK. \& El-Senaity MH. (2009). Chemical composition of raw milk and heavy metals behavior during processing of milk products. Global Veterinaria 3(3): 268-275.

Eskandari MH. \& Pakfetrat S. (2014). Aflatoxins and heavy metals in animal feed in Iran. Food Additives \& Contaminants: Part B 7(3): 202-207.

Essentail Korfali SI. \& Hamdan WA. (2013). Essentail and Toxic Metals in Lebanese Marketed Canned Food: Impact of Metal Cans. Journal of Food Research 2(1): 19.

Fakhari F., Shahbazi Y. \& Ahmadi F. (2014). Measurement of lead and cadmium in the samples of raw and pasteurized milk produced in the industrial cities of the anodic and cathodic voltammetry Arysazy. The second National Conference on health and nutritional significance of milkfrom production to consumption. 
Fallah SS., Fahimdanesh M. Reza M. (2015). Investigation of effect of grilland soak in citric acid and then grillon the changes of fe, pb and cd in sheep's liver. International Journal of Biology, Pharmacy and Allied Science 4(5): 39-47.

Farid SM. (2004). Determination of trace elements in cow's milk in Saudi Arabia. Engineering Sciences 15(2).

Farrah H. \& Pickering WF. (1977). The sorption of lead and cadmium species by clay minerals. Australian Journal of Chemistry 30(7): 1417-1422.

Garcia EM., Lorenzo ML., Cabrera C., Lopez MC. \& Sanchez J. (1999). Trace element determination in different milk slurries. Journal of dairy research 66(04): 569-578.

Goyer RA. (1995). Nutrition and metal toxicity. The American journal of clinical nutrition 61(3), 646S-650S.

Hamidpour M., Kalbasi M., Afyuni M., Shariatmadari H. \& Furrer G. (2011). Sorption of lead on Iranian bentonite and zeolite: kinetics and isotherms. Environmental Earth Sciences 62(3): 559-568.
Jaberi E., Shakerian A. Ebrahimi R. (2013). Study amount of lead and cadmium in Ultra Filtrate cheese and yogurt production in factory in Isfahan Pegah Milk and Golpayegan. Journal of food hygiene 3(3): 49-55.

Jahromi EZ., Bidari A., Assadi Y., Hosseini MRM. \& Jamali MR. (2007). Dispersive liquid-liquid microextraction combined with graphite furnace atomic absorption spectrometry: Ultra trace determination of cadmium in water samples. Analytica Chimica Acta 585(2): 305-311.

Javadi I, Haghighi B. \& Nejat H. (2005). Evaluation and dete.rmination of toxic metals (mercury, lead, cadmiun, and chromium) in cow milk. research journal of university of isfahan "science" 22(2): 57-70.

Jeng SL, Lee SJ. \& Lin SY. (1994). Determination of cadmium and lead in raw milk by graphite furnace atomic absorption spectrophotometer. Journal of dairy science 77(4): 945-949.

Khan ZI., Ahmad K., Bayat A., Mukhtar MK. \& Sher M. (2013). Evaluation of 
lead concentration in pasture and milk: A possible risk for livestock and public health. Pakistan Journal of Zoology 45(1): 79-84.

Kinoshita H., Sohma Y., Ohtake F., Ishida M., Kawai Y., Kitazawa H. \& Kimura K. (2013).Biosorption of heavy metals by lactic acid bacteria and identification of mercury binding protein. Research in microbiology 164(7): 701-709.

Li Y., McCrory D.F., Powell JM., Saam H. \& Jackson-Smith DA. (2005). Survey of selected heavy metal concentrations in Wisconsin dairy feeds. Journal of Dairy Science 88(8): 2911-2922.

Licata P., Trombetta D., Cristani M., Giofre F., Martin D., Calo M. \& Naccari F. (2004). Levels of "toxic" and "essential" metals in samples of bovine milk from various dairy farms in Calabria, Italy. Environment International 30(1): 1-6.

Mahmoudi R. Zare P. (2013). Total and M1 aflatoxins contamination in meat and milk buffalo were slaughtered in the northwest of Iran. Journal of food research 24(1): 11-18.
Mahmoudi R., Gajarbeygi P. \& Emami J. (2015). Honey contamination with heavy metals in Iran. The Journal of Qazvin University of Medical Sciences 18(5): 67-70.

Mahmoudi R., Mardani K. Rahimi B. (2015). Analysis of Heavy Metals in Honey from NorthWestern Regions of Iran. Journal of Chemical Health Risks 5(4): 251-256.

Mahmoudi R. \& Norian R. (2014). Aflatoxin B1 and M1 contamination in cow feeds and milk from Iran. Food and Agricultural Immunology 26 (1): 1-7.

Malakootian M. Golpayegani A. (2013). Determination of $\mathrm{Pb}, \mathrm{Cd}, \mathrm{Al}, \mathrm{Zn}$ and $\mathrm{Ca}$ in infant formula and baby foods in Iran and estimation of daily infant intake of these metals. Iranian Journal of Nutrition Sciences \& Food Technology 8(3): 251-259.

Moallembandani H., Rajabian M., Alimalayeri F., Mohammadi V., Arefi D., Dahmardeh S., Mohammadi S. \& Shahruzian A. (2014). Determination of Lead and Cadmium Level in Cow's Milk by Spectrophotometry Electrothermal Atomic Absorption in 
Zabol City. Scientific Journal of Ilam University of Medical Sciences 23(3): 178-185.

Mohammadi S., Nik poyan $\mathrm{H}$. \& Moushiri rodsari R. (2009). Determination of heavy metals in liquid whey and dry in plants of Khorasan Razavi Province. Innovation in food science and technology (journal of food science and technology) 1(3): 17-22.

Mollaei Parvary M., karim G., Ahmadi M. (2015). Determination of lead and cadmium contamination levels in industrial milk powders produced in Tehran. Journal of Food Hygiene 4(16): 69-75.

Navab irani M. (2000). Determination of Copper level in some infant milk powders using Spectophotometery. Thesis, Faculty of Pharmacy, Tehran University of MedicalSciences.

Nurdin E., Putra DP. \& Amelia T. (2013). Analysis of heavy metal lead $(\mathrm{Pb})$ levels with Aas in cow's milk by giving cumin (Cuminum cyminum L.), white turmeric (Curcuma zedoaria Rosc.) and mango turmeric (Curcuma mangga Val.). Pakistan
Journal of Biological Sciences 16(21): 1373.

Parveez Mand Zamaian F. (2001). Determination of lead and Cadmium in Tehran pasteurized milk. 12thNational Congress of Food Technology. October 9-10, Islamic Azad University, Tehran, Iran.

Patra RC., Swarup D., Kumar P., Nandi D., Naresh R. \& Ali SL. (2008). Milk trace elements in lactating cows environmentally exposed to higher level of lead and cadmium around different industrial units. Science of the total environment 404(1): 36-43.

Pavlovic I., Sikiric M., Lukac-Havranek J. \& Plavljanic N. (2004). Brajenovic N. Lead and cadmium levels in raw cow's milk from an industrialised Croatian region determined by electrothermal atomic absorption spectrometry.Czech Journal of Animal Science 49(4): 164-168.

Penaud S., Fernandez A., Boudebbouze S., Ehrlich SD., Maguin E. \& Van De Guchte M. (2006). Induction of heavy-metal-transporting CPX-type ATPases during acid adaptation in Lactobacillus bulgaricus. Applied and 
environmental microbiology 72(12): 7445-7454.

Poursartip M. (1999). Determination of Copper level in infant milk powder. Thesis, Faculty of Pharmacy, Tehran University of Medical Sciences.

Qin LQ., Wang XP., Li W., Tong X. \& Tong WJ. (2009). The minerals and heavy metals in cow's milk from China and Japan. Journal of health science 55(2): 300-305.

Radmehr B., Nematparvar M., Farhoodi MM. \& Khoshnevis M. Correlation between lead concentration in produced milk and drinking water in a few dairy farms of tehran province 2010.

Radmehr B., Nematparvar M., Moghadam Farhoodi M. \& Khoshnevis M. (2010). Correlation between Lead Concentration in Produced Milk and Drinking Water in a few Dairy Farms of Tehran province. Journal of veterinary clinical research 1(1): 4956.

Rahimi E. \& Derakhshesh SM. (2010). Investigation of Cadmium level in cow's raw milk from different regions of Iran. Journal of Veterinary Laboratory Research 2(1): 65-73.

Rokni N. (2007). Principles of food hygiene.Tehran, pp: 4350.

Shahbazi Y., Ahmadi F. \& Fakhari F. (2016). Voltammetric determination of $\mathrm{Pb}, \mathrm{Cd}, \mathrm{Zn}, \mathrm{Cu}$ and $\mathrm{Se}$ in milk and dairy products collected from Iran: An emphasis on permissible limits and risk assessment of exposure to heavy metals. Food chemistry (192) 1060-1067.

Shahmohammadi HZ., Moazed H., Jafarzadeh HNE. \& Haghighat JP. (2008). Removal of low concentrations of cadmium from water using improved rice husk. water and wastewater 19(6): 27-33.

Shakerian A. \& Karim G. (2004). Study on the contamination of milk and some milk products with Lead and Cadmiumin Esfahan and the effect of fatseparation using atomic absorption spectrophotometery. Journal of Iran Veterinary Sciences 2: 29-35.

Shirvani M., Kalbasi M., Shariatmadari H., Nourbakhsh F. \& Najafi B. (2006). Sorption-desorption of cadmium in 
aqueous palygorskite, sepiolite, and calcite suspensions: isotherm hysteresis. Chemosphere 65(11): 2178-2184.

Tajkarimi M., Faghih MA., Poursoltani H., Nejad AS., Motallebi AA. \& Mahdavi H. (2008). Lead residue levels in raw milk from different regions of Iran. Food Control 19(5): 495-498.

Vahidinia AA., Salehi I., Beygi nejad H., Pourtaghi J., Nazari Z. \& Mouradi MR. (2013). The study of lead and cadmium and related factors in raw milk produced in various regions of Hamedan Province. Journal of food hygiene 3(3): 39-47.
Vos G., Lammers H. \& Van Delft W. (1988). Arsenic, cadmium, lead and mercury in meat, livers and kidneys of sheep slaughtered in the Netherlands. Zeitschrift für Lebensmittel-Untersuchung und Forschung 187(1): 1-7.

Yasaei Mehrgrdy Gh., R., Ezzatpanah H., Yasini Ardakani SA. \& Dadfarnia Sh. (2010). Assessment of Lead and Cadmium Levels in Raw Milk from Various Regions of Yazd Province. Food Technology \& Nutrition 7(3): 35-43. 